\title{
Studies on Survival of Corneal Tissue Transplantation in Patients with Keratoconus
}

Giovanna Karinny Pereira Cruz ${ }^{1}$, Diana Paula de Souza Rego Pinto Carvalho', Isabelle Campos de Azevedo ${ }^{1}$, Rita de Cássia Lira da Silva ${ }^{1}$, Jéssica Valeska Herculano Lima ${ }^{1}$, Sandra Lúcia Arantes ${ }^{1}$, Allyne Fortes Vitor ${ }^{1}$, Viviane Euzébia Pereira Santos ${ }^{1}$, Maria Lúcia Ivo ${ }^{2}$, Marcos Antonio Ferreira Junior ${ }^{1}$

\section{Abstract}

Objective: To analyze the investigations regarding the survival of corneal tissue transplanted into patients affected by keratoconus.

Method: This is a review study with the following guiding question: "What are the factors that influence the survival of transplanted corneal tissue in patients with keratoconus?" An integrative review protocol was built for this study to ensure methodological rigor required. The sample selection was through a survey of articles in electronic databases PubMed/MEDLINE, Cumulative Index to Nursing and Allied Health Literature (CINAHL), Scopus and Science Direct in October 2014. Indexed descriptors in MeSH and/or synonyms were used: "keratoconus"; "Corneal transplantation" or "keratoplasty"; "Survival analysis" or "analysis of survival" or "method Kaplan-Meier."

Results: The final sample were thirteen articles available in full in accessible databases. Most of the studies were presented in the retrospective cohort design and used the Kaplan-Meier method for survival analysis. This data varied according to the surgical technique used and the factors that interfere in episodes of rejection postoperatively.

Conclusion: The survival of corneal tissue was directly related to the main factors involved in post-transplantation, like rejection, vascular changes, adopted surgical technique and inflammatory processes.

\section{Keywords}

Corneal Transplantation; Survival Analysis; Kaplan-Meier Method; Prospective Care; Keratoconus. 


\section{Introduction}

Keratoconus is a corneal ectasia, which affects $11 / 1300$ individuals worldwide, with more frequent appearance during puberty or second decade of life and progresses to the next two decades until it stabilize. It is a non-inflammatory medical condition, progressive, causing biomechanical changes in corneal structure and modifies its normal curvature in a cone shape, which results in diminished visual acuity from severe astigmatism, scars and ultimately, loss of vision in one-fifth of patients needing corneal transplantation to restore the vision [1, 2].

Based on the natural course and severity of ectasia, keratoconus can be divided into four phases: pre-clinical, the initial clinical stage, advanced stage and the stage of the complication. In the later stages, the changes are evident, with the appearance of opacities and low visual acuity. Thus, the corneal transplantation becomes the only viable therapeutic approach for keratoconus in advanced stages. By transplantation, the corneal stroma may regain its normal thickness; the cornea will return to its initial curvature, and high myopia and irregular astigmatism are reduced, which can significantly improve the vision $[3,4]$.

A prospective multicenter study by the Collaborative Longitudinal Evaluation of Keratoconus reported $12 \%$ rate of keratoplasty during an eight-year follow-up period in patients with keratoconus. The Australian Corneal transplant registry report in 2012 shows an average survival of transplanted corneal graft for keratoconus treatment of over eighteen years. The graft survival rate in one, five, ten, fifteen and twenty years were 97\%, 95\%,89\%, 77\% and $46 \%$ respectively $[5,6]$.

Studies indicate that the survival of keratoplasty depends on several factors, many of them not fully understood. It is necessary to look for evidence on the factors that influence the survival of transplanted cornea by the types of diseases that affect the cornea $[7,8]$.
In this perspective, this study aimed to analyze the investigations regarding the survival of corneal tissue transplanted into patients affected by keratoconus.

\section{Method}

This is an integrative review study (IR) of the literature, on the survival of transplanted corneal tissue in patients with keratoconus and the factors that interfere in this survival. This review followed a methodological reference that offers six steps for their development: 1) elaboration of a guiding question, 2) search or sampling in the literature, 3) categorization, 4) critical analysis of the studies included, 5) discussion of results and 6) synthesis of the integrative review. In this context, a revised protocol was previously prepared to guide the development of research and the realization of all six suggested steps [9].

Protocol was developed to perform the search and sampling and development of the form of research to carry out it systematically by researchers and maintain the necessary rigor. The topic identification, the objective, the guiding question, the selection of the study sample by couples search strategy in databases, using controlled and uncontrolled descriptors, the preparation of inclusion and exclusion criteria of studies, the categorization of results, evaluation of the studies included in the review and finally the synthesis of knowledge were the protocol steps.

The main question that supports the development of the research was: What are the factors that influence the survival of transplanted corneal tissue in patients with keratoconus? For the selection of the sample of the study, a survey of the texts was carried out in electronic databases PubMed/MEDLINE, Cumulative Index to Nursing and Allied Health Literature (CINAHL), Scopus and Science Direct in October 2014, in which the indexed descriptors used were in MeSH or synon- 
yms "keratoconus" (1); "Corneal transplantation" (2) OR "keratoplasty" (3); "Survival analysis" (4) OR "analysis of survival" (5) OR "method KaplanMeier" (6).

These descriptors enabled six different crossings (\#) respectively inserted in all selected database. They are: \#1) "keratoconus" AND "corneal transplantation" AND "survival analysis" \#2) "keratoconus" AND "corneal transplantation" AND "analysis of survival" \#3) "keratoconus" AND "corneal transplantation" AND "method KaplanMeier" \#4) "keratoconus" AND "keratoplasty" AND "survival analysis" \#5) "keratoconus" AND "keratoplasty" AND "analysis of survival" \#6) "keratoconus" AND "keratoplasty" AND "method Kaplan-Meier".

Only texts in the form of scientific articles available for free and in full in the databases selected for access by Proxy UFRN, in Portuguese, English and Spanish, without time limit, as the corneal transplant a practice of secular development were included. The manuscripts were selected as the theme by eligibility criteria pre-established by title, abstract and full reading of the studies.

Articles excluded were those that do not address a relevant way in the subject to answer the guiding question, studies that addressed the survival of corneal tissue transplanted in patients with other indications previous diagnoses trans- plantation, publications such as dissertations, theses, reviews, editorials and notes to the editor, and the duplicate articles which were only recorded once.

\section{Results}

There were 3,272 references initially identified in the four databases listed through the crossings with the descriptors. After the first selection by title and abstract, there were 33 studies, which three publications were excluded by being duplicated. Table 1 shows the consulted search strategies and their bases, as well as the total amount recovered and references title selected after analysis and abstract of each study [10].

Most references excluded in the analysis process addressed the survival of transplanted corneal tissue by an indication of other clinical and pathological conditions different from keratoconus or did not refer to any specific diagnosis.

From the application of the screening test, which includes the application of the guiding question and the inclusion/exclusion criteria in the title, abstract and text, it was possible to reach the final sample of this research, finding four articles in PubMed/MEDLINE, no articles in the CINA$\mathrm{HL}$, six studies in ScienceDirect and three articles in Scopus, a final total of 13 selected studies.

Table 1. Consulted databases, search strategies, recovered and selected references - Natal/RN, 2014.

\begin{tabular}{|c|c|c|c|}
\hline Database & Syntax used & $\begin{array}{l}\text { References } \\
\text { recovered }\end{array}$ & $\begin{array}{l}\text { References } \\
\text { selected by title } \\
\text { and abstract }\end{array}$ \\
\hline CINAHL & $\begin{array}{l}\text { \#1 (TX All Text); \#2 (TX All Text); \#3 (TX All Text); \#4 (TX All Text); } \\
\text { \#5 (TX All Text); \#6 (TX All Text) }\end{array}$ & 10 & 0 \\
\hline PubMed/MEDLINE & \#1 OR \#2 OR \#3 OR \#4 OR \#5 OR \#6 & 277 & 5 \\
\hline Science Direct & $\left(1^{\circ}\right)$ AND $\left(2^{\circ}\right.$ OR $\left.3^{\circ}\right)$ AND $\left(4^{\circ}\right.$ OR $5^{\circ}$ OR $\left.6^{\circ}\right)$ & 2.400 & 8 \\
\hline Scopus & $\begin{array}{l}\operatorname{ALL}\left(1^{\circ}\right) \text { AND ALL }\left(2^{\circ} \text { AND } 4^{\circ}\right) \text { OR ALL }\left(2^{\circ} \text { OR } 6^{\circ}\right) \text { OR ALL } \\
\left(3^{\circ} \text { AND } 4^{\circ}\right) \text { OR ALL }\left(3^{\circ} \text { AND } 5^{\circ}\right) \text { OR ALL }\left(3^{\circ} \text { AND } 6^{\circ}\right)\end{array}$ & 585 & 20 \\
\hline Total & & 3.272 & 33 \\
\hline
\end{tabular}


Table 2 shows 13 articles of the final sample of this study. During the analysis of the full text, conceptual similarity of keratoconus were noticeable significant and a predominance of studies with the research design type of retrospective cohort.
Table 3 shows the major survival rates and the most prevalent factors that intervene, according to the studies analyzed.

Table 2. Authors, year of publication, design, and objective of the study - Natal, 2014.

\begin{tabular}{|c|c|c|c|}
\hline & Author/Year & Research design & Objective \\
\hline A & Al-Mohaimeed MM (2013). & Cohort retrospective & $\begin{array}{l}\text { To evaluate complications and results of visual and graft survival } \\
\text { in eyes that underwent penetrating keratoplasty (PK) for } \\
\text { keratoconus. }\end{array}$ \\
\hline B & $\begin{array}{l}\text { Han DCY, Mehta JS, Por } \\
\text { YM, Htoon HM, Tan DTH } \\
\text { (2009). }\end{array}$ & Cohort retrospective & $\begin{array}{l}\text { To compare the results after PK and two lamellar keratoplasty } \\
\text { previous techniques (DALK) in patients with keratoconus. }\end{array}$ \\
\hline C & $\begin{array}{l}\text { Jonuscheit S, Doughty MJ, } \\
\text { Ramaesh K (2013). }\end{array}$ & Cohort & $\begin{array}{l}\text { To evaluate the corneal endothelium results and postoperative } \\
\text { visual complications of corneal transplantation for keratoconus. }\end{array}$ \\
\hline D & $\begin{array}{l}\text { Kasbekar SA, Jones MA, } \\
\text { Ahmad S, Larkin DFP, Kaye } \\
\text { S (2014). }\end{array}$ & Cohort multicenter & $\begin{array}{l}\text { To investigate a graft survival and surgical experience in clinical } \\
\text { outcome after DALK. }\end{array}$ \\
\hline E & $\begin{array}{l}\text { Kelly TL, Coster DJ, } \\
\text { Williams KA (2011). }\end{array}$ & Cohort retrospective & $\begin{array}{l}\text { To determine the factors that influence the survival of a } \\
\text { corneal graft in PK in keratoconus patients who received } \\
\text { retransplantation after the failure of a first graft. }\end{array}$ \\
\hline $\mathrm{F}$ & $\begin{array}{l}\text { Kelly TL, Williams K A, } \\
\text { Coster, Douglas J (2011). }\end{array}$ & Cohort & $\begin{array}{l}\text { To determine the factors that influence the survival of long-term } \\
\text { graft and visual acuity in } 4834 \text { eyes. }\end{array}$ \\
\hline G & $\begin{array}{l}\text { Kubaloglu A, Koytak A, } \\
\text { Sari ES, Akyol S, Kurnaz E, } \\
\text { Ozerturk Y (2012). }\end{array}$ & Cohort retrospective & $\begin{array}{l}\text { To compare the state of the corneal endothelium and central } \\
\text { corneal thickness in the first four years of post-operative after } \\
\text { DALK and PK in patients with keratoconus. }\end{array}$ \\
\hline $\mathrm{H}$ & $\begin{array}{l}\text { Lim L, Pesudovs K, Coster } \\
\text { DJ (2000). }\end{array}$ & Retrospective study & $\begin{array}{l}\text { To determine long-term effect on the PK's vision held for } \\
\text { keratoconus. }\end{array}$ \\
\hline I & $\begin{array}{l}\text { Niziol LM, Musch DC, } \\
\text { Gillespie BW, Marcotte LM, } \\
\text { Sugar A (2013). }\end{array}$ & $\begin{array}{l}\text { Retrospective case } \\
\text { series }\end{array}$ & $\begin{array}{l}\text { To estimate the probability of graft rejection, rejection, recurrent } \\
\text { keratoconus (KC) to assess the specific vision of quality in } 20 \text { to } \\
25 \text { years after penetrating keratoplasty for keratoconus. }\end{array}$ \\
\hline J & $\begin{array}{l}\text { Pramanik S, Musch DC, } \\
\text { Sutphin JE, Farjo AA } \\
\text { (2006). }\end{array}$ & $\begin{array}{l}\text { Retrospective, } \\
\text { consecutive, series of } \\
\text { non-comparative cases. }\end{array}$ & $\begin{array}{l}\text { To evaluate graft survival in long-term PK for keratoconus after } \\
20 \text { years, determine the } \mathrm{KC} \text { rate and enjoy the functional visual } \\
\text { results, as well as the development of glaucoma. }\end{array}$ \\
\hline K & $\begin{array}{l}\text { Rahimzadeh M; Hajizadeh } \\
\text { E, Feizi S (2010). }\end{array}$ & Cohort retrospective & $\begin{array}{l}\text { To estimate the rate of healing after the graft rejection in } \\
\text { bilateral corneal transplants in Iranian patients with keratoconus } \\
\text { and to determine risk factors associated with rejection. }\end{array}$ \\
\hline $\mathrm{L}$ & $\begin{array}{l}\text { Tuft JS, Gregory WM, } \\
\text { Davison CR (1995). }\end{array}$ & Cohort retrospective & $\begin{array}{l}\text { To determine the effect of bilateral surgery, penetrating } \\
\text { keratoplasty performed for keratoconus on the rejection-free } \\
\text { survival. }\end{array}$ \\
\hline M & $\begin{array}{l}\text { Zhang Y-M, Wu S-Q, Yao } \\
\text { Y-F (2013). }\end{array}$ & Cohort retrospective & $\begin{array}{l}\text { To compare the postoperative results of DALK with PK in the } \\
\text { treatment of keratoconus. }\end{array}$ \\
\hline
\end{tabular}


Table 3. Main interfere survival rates and factors - Natal/RN, 2014.

\section{Survival rates}

A Survival probabilities - 99.8\% at 1 year, $97.6 \%$ at 5 years after transplantation.

B Survival of the PK group - 100\% in 12, 24, 36, 48 and 60 months, $97.6 \%$ after 60 months and $48.8 \%$ after 10 years. The group DALK - 100\% at 12, 24 and 36 months.

C Survival rate at one year of 95\%. After 34 years (411 months) $37 \%$ survival rate.

D The graft survival was $92 \%$ for PK and $90 \%$ for DALK.

E Survival at 1, 5, and 15 months - 88\%, 69\% and $46 \%$ for the second graft; $65 \%, 49 \%$ and $33 \%$ for the third graft.

F Survival rate $-89 \%, 49 \%$ and $17 \%$ at 10,20 and 23 , respectively.

$G$ The average annual rate of endothelial cell loss was calculated at $14.12 \%$ per year in the PK Group and $5.78 \%$ per year in the DALK group.

H Graft failure at 46 months after transplantation was $1.08 \%$.

I Survival of $33 \%, 45 \%, 46 \%$ and $48 \%$ at $1,5,10$ and 20 , respectively.

J Survivals in 20 and 25 years were $93.7 \%$ and $85.4 \%$, respectively.

K Survivals of 1.5 and 10 years were $82 \%, 74 \%$, and $70 \%$, respectively.

L Survival 98.3\% 98.3\% 95.6\% $\%$ and $82,112,24$, 60 and 90 months atopic group and 97.8\%, 96.5\%, $93.4 \%$ and $85.7 \%$ in $12,24,60$ and 126 months on non-atopic group.

M The survival rate of $100 \%$ from 1 to 9 years with DALK technique; $97.4 \%$ survival of 3 to 10 years with the use of PK technic.

\section{Factors that interfere with survival}

Rejection episodes.

Episodes of endothelial rejection/Surgical technique.

Loose sutures, epithelial defects, rejection episodes, folds of Descemet membrane induced increase in intraocular pressure steroids and persistent astigmatism.

Ocular surface diseases, the difference between the diameter of the corneal button donor-recipient of $0.5 \mathrm{~mm}$, surgical technique, endothelial, stromal rejection, and rejection.

Re-transplant, previous graft failure in less than 10 years, receptor age equal or over 60 years, episodes of rejection and corneal neovascularization.

Time for suture removal, microbial keratitis or uveitis after grafting, corneal vascularization before or after the graft receptor's age, rejection episodes, graft size, the surgeon's workload.

Surgical technique, endothelial cell loss.

Graft vascularization, loose sutures, and rejection.

Recurrent keratoconus, corneal donor button size, astigmatism.

Recurrent keratoconus

Vascularization of the cornea receptor's age.

Endothelial rejection, fungal keratitis.

Graft rejection, glaucoma, cataracts, loss of endothelial cells, wound dehiscence. 


\section{Discussion}

In the dependent variable survival analysis, it is always the time of occurrence of a certain event. In this case, it analyzes the time at which the participants developed the certain event, after a certain period [11].

Most studies used the method of Kaplan-Meier for survival analysis in which the time intervals are not fixed but determined by the occurrence of a failure $[12,13]$.

Keratoconus was one of the main causes for corneal transplantation and may be a procedure performed by various surgical techniques, especiaIly penetrating keratoplasty (PK) and deep anterior lamellar keratoplasty (DALK). In this respect, the selected studies show survival rates and factors affecting mainly dependent on the surgical technique used.

In one study, the follow-up period was divided into two-time intervals, the first of 0 to 18 months and the second of 18-221 months. It was concluded that the risk of graft rejection in the first period is about six times higher than in the second time interval [14].

Studies for factors that affect survival show that postoperative risk factors play an important role in graft survival in the long term than the preoperative factors [15].

The main factors affecting the survival of corneal graft for the treatment of keratoconus showed by studies in descending order of prevalence were: rejection episodes (study A, B, C, D, E, F, H, L and M) changes in corneal vascularization $(E, F, H, K)$, the surgical technique adopted $(B, D$ and $G$ ), the size of the corneal button used ( $F, D$ and $I$ ) receptor's age $(E, F$ and $K)$, suture characteristics $(C$ and $H)$, development of inflammatory processes ( $F$ and $L)$, astigmatism ( $C$ and I), endothelial cell loss ( $G$ and $\mathrm{M})$ and recurrent keratoconus (I and J).

Three Studies (B, D, G) address the surgical technique as a factor directly related to the survival of corneal graft. PK is an intraocular procedure, in contrast to DALK, non-penetrating and extraocu- lar procedure. The absence of endothelial rejection with DALK technique is an advantage over the PK, although the endothelial rejection rates in PK keratoconus are low. The loss of endothelial cells in this technique occurs at a faster pace than in DALK. However, patients undergoing DALK remain susceptible to stromal rejection, although such episodes are less frequent [16-18].

Factors such as pre-corneal vascularization after transplantation, the size of the corneal button above the receptor, the age of the upper receptor to sixty years, loose sutures, inflammatory processes such as uveitis and keratitis, presence of post-transplant astigmatism, loss of cells endothelial and recurrent keratoconus are factors that interfere negatively in failure of corneal graft.

Some factors appeared less frequently in this review, such as glaucoma, cataracts, wound dehiscence induced increase in intraocular pressure steroids corneal surface disease, re-transplantation, failure of the previous graft in less than ten years, the surgical site, epithelial effects and surgeon's workload. However, when analyzed in their studies individually, they showed significance with direct interference in the success of transplanted tissue [19-24].

One of the main limitations of the studies found was the loss of follow-up records since there may be many patients with long-surviving grafts that did not attend follow-up visit for years. This loss can lead to an underestimation of longer survival of transplanted corneal tissue. Thus, data can become biased, so that the failure rate is overestimated [8].

\section{Conclusion}

The survival of corneal tissue is directly related to the main factors involved in post-transplant, like rejection, vascular changes, a surgical technique adopted details and inflammatory processes. Thus, the control subject to monitoring factors and prevention of installation is required for surgical success and increased survival of the grafted tissue and better quality of life of the individual. 
Therefore, it is necessary to ensure the continuity of post-operative care, and awareness of self-care and attention to the cases of abandonment of therapy, since the main factors that influence the survival of corneal graft can be prevented.

\section{Acknowledgment}

To the Coordination of Higher Education Personnel (CAPES - Masters scholarship).

\section{References}

1. Romero-Jimenez M, Santodomingo-Rubido J, Wolffsohn JS. Keratoconus: a review. Cont Lens Anterior Eye. 2010; 33: 157-66.

2. Vazirani J, Basu S. Keratoconus: current perspectives. Clin Ophthalmol. 2013; 7: 2019-30.

3. Piñero DP, Alió JL, Alesón A, Vergara ME, Miranda M. Corneal volume, pachymetry, and correlation of anterior and posterior corneal shape in subclinical and different stages of clinical keratoconus. J Cataract Refract Surg. 2010; 36(5): 814-25.

4. Rabinowitz YS. Ceratocone. Surv Ophthalmol. 1998; 42(4): 297319.

5. Gordon MO, Steger-May K, Szczotka-Flynn L, Riley C, Joslin $\mathrm{CE}$, Weissman BA et al. Baseline factors predictive of incident penetrating keratoplasty in keratoconus. Am J Ophthalmol. 2006; 142(6): 923-30.

6. Williams KA, Lowe MT, Keane MC, Jones VJ, Loh RS, Coster DJ. The Registry corneas Australian. 2012

7. Wagoner MD, Ba-Abbad R, Al-Mohaimeed M, Al-Swailem S, Zimmerman MB. Postoperative complications after primary adult optical penetrating Keratoplasty: prevelance and impact on graft survival. Cornea. 2009; 28(4): 385-94.

8. Kelly T, Willians KA, Coster D J. Corneal Transplantation for Keratoconus: a registry study. Arch Ophthalmol. 2011; 129(6): 691-7.

9. Whittemore $R$, Knafl $K$. The integrative review: updated me $\rightarrow$ thodology. J Adv Nurs. 2005; 52(5): 546-53.

10. Soares CB, Hoga LAK, Peduzzi M, Sangaleti C, Yonekura T, Silva DRAD. Revisão integrativa: conceitos e métodos utilizados na enfermagem. Rev Esc Enferm USP. 2014; 48(2): 335-45.

11. Botelho F, Silva C, Cruz F. Epidemiologia explicada - Análise de Sobrevivência. Acta Urol. 2009; 26(4): 33-38.

12. Bustamante-Teixeira MT, Faerstein E, Latorre MR. Técnicas de análise de sobrevida. Cad Saúde Pública. 2002; 18(3): 579-594.

13. Kelly TL, Coster DJ, Williams KA. Repeat Penetrating Corneal Transplantation in Patients with Keratoconus. Ophthal. 2011; 118(8): 1538-42.

14. Rahimzadeh M; Hajizadeh E, Feizi S. Cure Rate Following Rejection in Bilateral Corneal Grafts for Keratoconus. J Ophthalmic Vis Res. 2010; 5(3): 145-50.
15. Jonuscheit S, Doughty MJ, Ramaesh K. The corneal endothelium after keratoplasty for keratoconus. Clin Exp Ophtalmol. 2013; 96(2): 201-207.

16. Al-Mohaimeed MM. Penetranting keratoplasty for keratoconus: visual and graft survival outcomes. 2013; 7(1): 67-74.

17. Han DCY, Mehta JS, Por YM, Htoon HM, Tan DTH. Comparison of Outcomes of Lamellar Keratoplasty and Penetrating Keratoplasty in Keratoconus. Am J Ophthal. 2009; 148(5): 74451.

18. Lim L, Pesudovs K, Coster DJ. Penetrating keratoplasty for keratoconus: visual outcome and success. Ophthalmol. 2000; 107(6): 1125-31.

19. Kasbekar SA, Jones MA, Ahmad S, Larkin DFP, Kaye S. Corneal Transplant Surgery for Keratoconus and the Effect of Surgeon Experience on Deep Anterior Lamellar Keratoplasty Outcomes. Am J Ophthalmol. 2014; 158(6): 1239-46.

20. Niziol LM, Musch DC, Gillespie BW, Marcotte LM, Sugar A. Long-Term Outcomes in Patients Who Received a Corneal Graft for Keratoconus Between 1980 and 1986. American J Ophthal. 2013; 155(2): 213-19.

21. Zhang Y-M, Wu S-Q, Yao Y-F. Long-term comparison of full-bed deep anterior lamellar keratoplasty and penetrating keratoplasty in treating keratoconus. J Zhejiang Univ Sci B. 2013; 14(5): 438-50.

22. Kubaloglu A, Koytak A, Sari ES, Akyol S, Kurnaz E, Ozerturk Y. Corneal endothelium after deep anterior lamellar keratoplasty and penetrating keratoplasty for keratoconus: A four-year comparative study. Indian J. Ophthalmol. 2012; 60(1): 35-40.

23. Pramanik S, Musch DC, Sutphin JE, Farjo AA. Extended Longterm Outcomes of Penetrating Keratoplasty for Keratoconus. Ophthal. 2006; 113(9): 1633-8

24. Tuft JS, Gregory WM, Davison CR. Bilateral Penetrating Keratoplasty for Keratoconus. Ophthal. 1995; 102(3): 462-8.
Publish in International Archives of Medicine

International Archives of Medicine is an open access journal publishing articles encompassing all aspects of medical science and clinical practice. IAM is considered a megajournal with independent sections on all areas of medicine. IAM is a really international journal with authors and board members from all around the world. The journal is widely indexed and classified Q1 in category Medicine. 